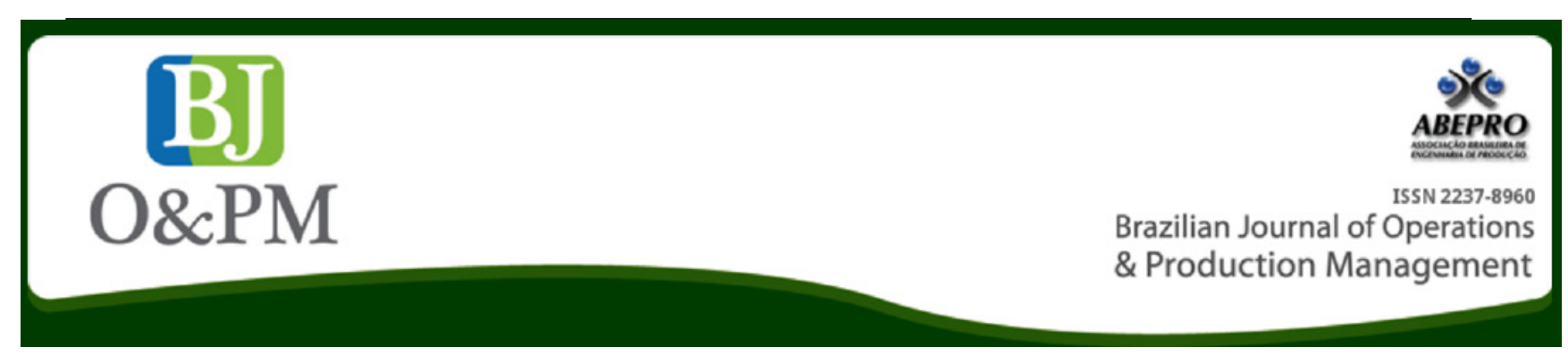

\title{
PRODUCT-SERVICE SYSTEMS AS SUSTAINABLE ALTERNATIVES TO MOBILITY: A COMPARATIVE ANALYSIS OF TWO BIKE-SHARING SYSTEMS
}

Thayla Tavares de Sousa-Zomera; Vinicius Zago Cantúa; Paulo Augusto Cauchick Miguela

${ }^{\text {a}}$ Federal University of Santa Catarina (UFSC) - Florianópolis, SC, Brazil

\begin{abstract}
Product-Service Systems (PSS) have been discussed as promising business models to redirect the contemporary production and consumption patterns towards sustainability. However, the research on PSS is mostly dictated by theoretical works and more empirical investigations are needed. Additionally, empirical studies that compare PSS solutions situated in different contextual conditions are required. This paper aims to analyze two use-oriented bike-sharing systems with sustainability potential in order to contribute to PSS empirical body of knowledge. A PSS located in a developed country and another one available in an emerging economy were selected to be investigated. A qualitative analysis was carried out considering the contextual conditions of each solution: PSS elements, sustainable business models components, and sustainability potential, based mainly on secondary data. The results confirmed that these PSS models can provide environmental, economic, and social benefits. The analysis and comparison between the solutions also demonstrated differences in both systems such as integration with other transportation modes and renewable energy usage that may affect customer acceptance and PSS sustainability performance. Customer behavior, acceptance and satisfaction need further study. Understanding the real factors that motivate customers to use a bike-sharing system in different contexts can be useful in efforts to spread its future adoption.
\end{abstract}

Keywords: product-service systems, PSS, bike-sharing systems, sustainability 


\section{INTRODUCTION}

A sustainable product-service system (PSS) can be defined as "an offer model providing an integrated mix of products and services that are together able to fulfill a particular customer demand (to deliver a 'unit of satisfaction'), based on innovative interactions between the stakeholders of the value production system (satisfaction system), where the economic and competitive interest of the providers continuously seeks environmentally and socio-ethically beneficial new solutions" (Vezzoli et al., 2015, p.2). PSS are innovative business approaches that shift the traditional business focus from selling only physical products (e.g. a washing machine) to selling a mix of products and services (e.g. cleaning services) that are jointly capable of fulfilling specific consumers' needs ('clean clothes') (Unep, 2015). When rightly designed, a PSS business model can increase resource efficiency, either as a product is used by several users, or as product longevity and resource efficiency are optimized through design and maintenance regimes, and through obsolescence plans (Overholm, 2015). PSS have been widely discussed as promising approaches to drive the current production and consumption patterns towards sustainability (Ceschin, 2013).

Product-service systems have become a popular subject and a wide range of research in the PSS and sustainability fields have been developed (Tukker, 2015). With a focus on a 'satisfaction-based' economy, PSS offers the potential for generating win-win solutions that promote profits, environmental and social benefits for low- and middleincome contexts with less economic possibilities (Unep, 2002; Ceschin, 2014; Chou et al., 2015). Nevertheless, although PSS is discussed as a promising solution to lowand middle-income contexts, those solutions have been mainly studied and implemented in developing economies. Therefore, a research gap exists regarding how PSS business models may provide social benefits in low and middleincome contexts in addition to the environmental and economic ones, as emphasized by literature (e.g. Vezolli et al., 2015).

In fact, PSS research is still dominated by theoretical work and more empirical investigations are necessary to contribute to the PSS theory-building (Beuren et al., 2013). Empirical investigations are also required to help identify the multiplicity of PSS solutions and their associated strategies and practices (Cook, 2014). Moreover, there are only a very few contributions that compare two or more PSS cases located in different countries, but it is necessary to study PSS solutions located in distinct contexts in order to avoid the creation of results that are applicable specific for one culture (Boehm and Thomas, 2013).

In this sense, this paper aims to analyze and to compare two PSS solutions. One is located in a developing country
(Brazil) and the other one in a developed economy (France). The PSS solutions under study consist of bike-sharing systems, an effective alternative to sustainable mobility, since in the move towards sustainable consumption and production patterns mobility is one of the priority areas (Zhang et al., 2015). The goal is to contribute to the body of knowledge by investigating and comparing two solutions operated in different contexts, which is still little discussed in the literature. Specifically, the purpose is to contribute to literature by identifying convergent aspects, the main differences concerning PSS implementation, the elements of this type of PSS as a sustainable business model, and to analyze the sustainability potential of both PSS solutions.

The remainder of this paper is structured as follows. After this introduction, next section presents a literature review by briefly covering PSS and sustainability issues as well as bike-sharing systems. The third section presents the research design in addition to the procedures adopted for data collection. The fourth section discusses the main results of the analysis and comparison of PSS solutions and, finally, concluding remarks are drawn in addition to some insights for future work.

\section{LITERATURE REVIEW ON PSS}

A PSS can be viewed as a business model (Boehm et Thomas, 2013; Overholm, 2015; Tukker, 2015). As a value proposition model, with emphasis on customer satisfaction by providing functions, PSS has four key elements (Mont, 2004): (i) products; (ii) services; (iii) actors network, and (iv) infrastructure. The products are the tangible artifacts of the system. The services cover all operations that make products available and support the products management during the use phase and end of life phase of the PSS life cycle. The network of actors includes all stakeholders involved to produce and to deliver the offer, including the partnerships and interactions between them. The infrastructure involves the existing collective and private systems to provide the delivery of the PSS offer.

PSS business models can be classified in different ways. The most discussed classification of PSS types in the literature is the one provided by Tukker (2004), which distinguish three main PSS categories: (i) product-oriented, (ii) use-oriented, and (iii) result-oriented. According to this classification, in the first main category (product-oriented), the business focus is on the sale of products with some extra services. In the useoriented category, the traditional product still plays a central role, but it stays in ownership with the provider. It is made available in different ways, like sharing, leasing, and pooling schemes. In the last category (result-oriented services), the customer and the provider agree on a result; there is no predetermined product involved. It also has been argued that different PSS categories could have different environmental 
potential, with result-oriented services having the greatest potential for environmental improvements (Tukker, 2004; Tukker, 2015).

Concerning PSS sustainability potential, the literature has been discussing a wide range of environmental, economic, and social benefits that PSS solutions can provide. In the economic dimension, PSS can potentially improve the competitiveness of the companies involved in producing and delivering the offer (Ceschin, 2014). A PSS offers the opportunity to decouple economic success from material consumption and hence reduce the environmental impact of economic activity (Baines et al., 2007). The environmental benefits of PSS are related to the fact that there is a potential economic and competitive incentive for the stakeholders involved in the PSS offer to optimize the material and energy consumption (Ceschin, 2014). Table 1 summarizes the main PSS sustainability benefits discussed in the literature, involving the three sustainability dimensions.

Despite the numerous sustainability benefits that can be generated by these business models, the implementation of PSS solutions remains an important research gap (Reim et al., 2015). Although PSS literature is expanding, there is concern that sustainable PSS has still not been widely implemented and diffused, because these new solutions

Table 1. PSS sustainability benefits

\begin{tabular}{|c|c|c|}
\hline $\begin{array}{l}\text { Sustainability } \\
\text { dimension }\end{array}$ & Benefits & References \\
\hline \multirow{9}{*}{ Environmental } & $\begin{array}{l}\text { Reduction of products manufactured by the introduction } \\
\text { of alternative usage scenarios }\end{array}$ & Beuren et al. (2013) \\
\hline & Materials and energy consumption optimization & UNEP (2002), Vezzoli (2007), Bocken et al. (2014) \\
\hline & Resources usage optimization & Baines et al. (2007), Vezzoli (2007), Bocken et al. (2014) \\
\hline & $\begin{array}{l}\text { Extension of the products life cycle through adding } \\
\text { services such as maintenance }\end{array}$ & UNEP (2002), Vezzoli (2007), Bocken et al. (2014) \\
\hline & Intensive use of products through sharing schemes & Vezzoli (2007) \\
\hline & $\begin{array}{l}\text { Use of more advanced and efficient technologies with } \\
\text { lower environmental impacts }\end{array}$ & Mont (2004), Vezzoli (2007) \\
\hline & Waste reduction & Baines et al. (2007) \\
\hline & Production and consumption patterns reorientation & Ceschin (2013) \\
\hline & Market opportunities and strategic positioning & $\begin{array}{l}\text { Goedkoop et al. (1999), UNEP (2002), Baines et al. } \\
\text { (2007), Ceschin (2014) }\end{array}$ \\
\hline \multirow[t]{6}{*}{ Economic } & Cost reduction through less use of materials and energy & Baines et al. (2007) \\
\hline & Customer loyalty & UNEP (2002) \\
\hline & $\begin{array}{l}\text { Customers access to products previously inaccessible by } \\
\text { acquisition }\end{array}$ & Mont and Tukker (2006) \\
\hline & $\begin{array}{l}\text { Added value for consumers by satisfying their needs with } \\
\text { functions without having to purchase the products }\end{array}$ & UNEP (2002), Ceschin (2014) \\
\hline & $\begin{array}{l}\text { Improving the life quality by providing solutions focused } \\
\text { on the needs and in the value delivered }\end{array}$ & Tukker and Tischner (2006), Ceschin (2014) \\
\hline & $\begin{array}{l}\text { Increasing in customers satisfaction by their involvement } \\
\text { in the offer development and customization }\end{array}$ & Tukker and Tischner (2006); Ceschin (2014) \\
\hline \multirow[t]{5}{*}{ Social } & $\begin{array}{l}\text { PSS offers are more accessible to consumers with few } \\
\text { economic possibilities }\end{array}$ & UNEP (2002), Vezzoli et al. (2015) \\
\hline & $\begin{array}{l}\text { Customers' education and reorientation of current } \\
\text { production and consumption patterns }\end{array}$ & Mont (2004), Bocken et al. (2014) \\
\hline & Jobs creation & UNEP (2002); Bocken et al. (2014) \\
\hline & New business opportunities for the local community & Tukker and Tischner (2006), Ceschin (2014) \\
\hline & Focus on local economy & UNEP (2002), Tukker and Tischner (2006), Vezzoli (2007) \\
\hline
\end{tabular}


Brazilian Journal of Operations \& Production Management

Volume 13, Número 3, 2016, pp. 264-275

DOI: 10.14488/BJOPM.2016.v13.n3.a4

challenge the existing consumption and production patterns (Ceschin, 2013). The identification and discussion of empirical examples and operational tactics can provide more information to companies that are in the transition and implementation of PSS solutions (Reim et al., 2015). In this sense, multiple case studies that exploit empirically PSS solutions are needed (Cook, 2014), because empirical research can allow to identify practices and emerging standards (Meredith, 1998), which are important for PSS theory-building. Moreover, the successful implementation of a PSS is highly dependent on the culture in which it will operate (Ceschin, 2014). Empirical studies comparing similar solutions in different contextual and cultural conditions such as those discussed in this paper are important for identifying aspects of PSS implementation in different contexts.

In this sense, PSS empirical investigations may contribute to PSS theory development and to improve new methodologies and operational solutions (Beuren et al., 2013). It is useful, therefore, to investigate existing cases to help better understand how PSS can be designed and implemented in order to facilitate customer acceptance and satisfaction. In fact, PSS empirical studies have been revealing diverse PSS designs and practices, each embedded in their own trajectories and institutional arenas (Cook, 2014) which are very important to theory development. The following section discusses bike-sharing systems, the PSS business model that is explored in this paper.

\subsection{An Overview of Bike-Sharing Systems}

A move towards sustainable mobility represents an increase in access to environmentally sustainable transport, especially for communities with a high percentage of lowincome households (Zhang et al., 2015). Considering the urban scale, mobility is one of the challenges that should be addressed and improved for a better quality of life for population (Keskin, 2006). Bike-sharing programs have emerged as an innovative approach to a growing number of cities (Fishman et al., 2014). In recent years, bike-sharing has become popular in the world (Tran et al. 2015). Bike-sharing is a convenient and 'green' transportation mode and, therefore, plays an important and complementary role in the comprehensive transportation system (Zhang et al., 2015). They can provide many benefits such as flexible mobility, pollution emissions reduction, physical activity benefits, reduced congestion and fuel use, individual financial savings and support for multimodal transport connections (Fishman et al., 2015).

Bike-sharing systems can be classified as use-oriented PSS solutions (according to Tukker, 2004 classification). The service provider retains the ownership in this PSS configuration and the customer purchases the use of the product/system over a given period or units of service (Zhang et al., 2015). These systems may allow environmental impacts minimization, due to considerably more intensive use or prolonged life of capital goods used in the system (Tukker, 2004). A system map is illustrated in Figure 1, which provides an overview of bike-sharing systems operation and elements involved in the offer. The main product of the system is the bicycle, and the main service is the provision of bicycles for transportation purposes. The other system elements will be discussed in details concerning each PSS solution analyzed in section 4.

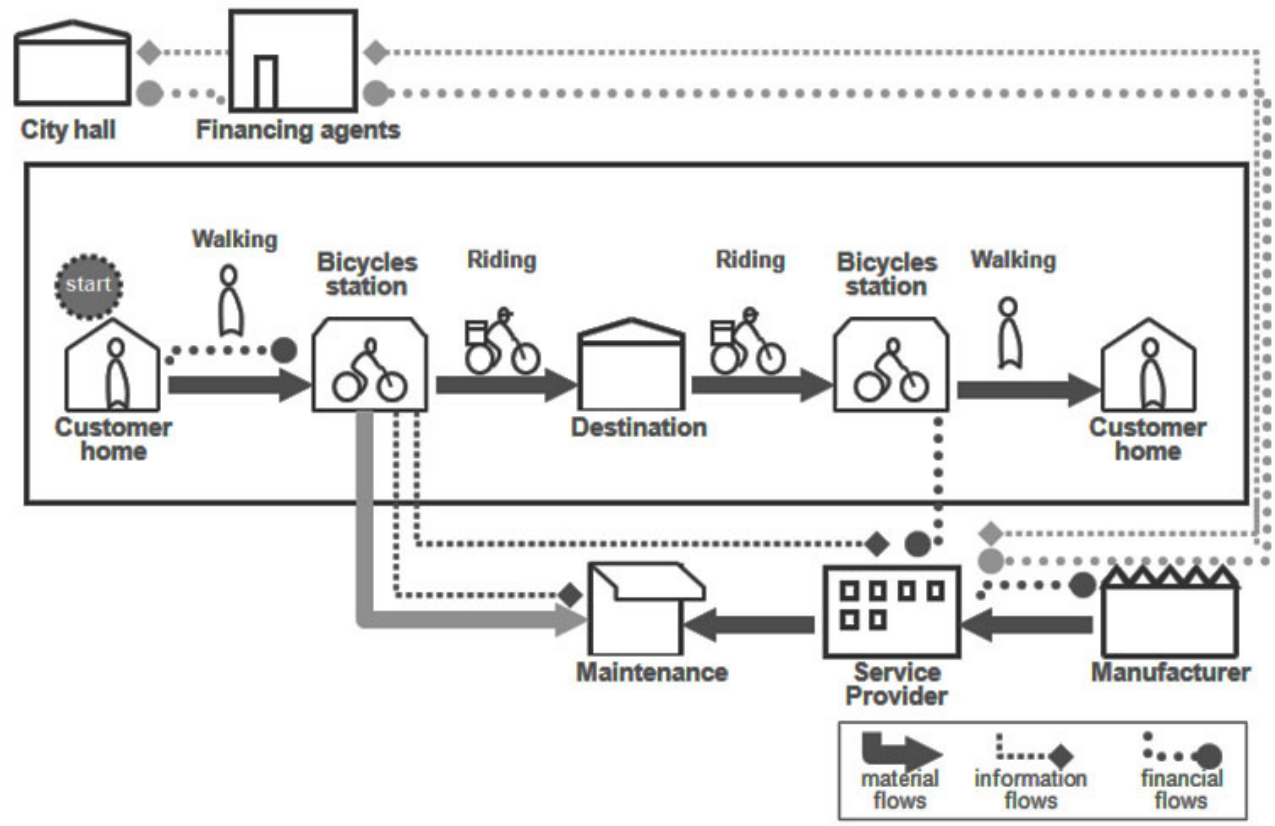

Figure 1. Bike-sharing system map 
However, although bike-sharing programs have existed for almost half a century, only in the recent decade the prevalence and popularity of these systems has increased (Fishman et al., 2014). In this sense, due to the popularity and the sustainability potential of this type of PSS, performing empirical studies that investigate the operational practices associated with these business models and their sustainability potential may be useful to PSS theory-building. Next section presents the research methods adopted to analyze and compare the PSS solutions under study.

\section{RESEARCH DESIGN}

This paper reports on the results of an explorative and qualitative study involving two business to consumer (B2C) PSS solutions, since knowledge and experience regarding PSS business models, are still limited (Beuren et al., 2013). Starting from a literature review in the subject, two PSS solutions were selected due to its sustainable potential and relevance as initiatives to expand sustainable transportation opportunities. These solutions are business models in expansion in many countries and cities around the world (Keskin, 2006) and they represent one of the most popular types of product-service systems discussed in the literature. In addition, similar to the work performed by Keskin (2006), both solutions were chosen according to their innovativeness in terms of products and services and organizational schemes, and according to each system location, to demonstrate the development and the sustainability potential of bike-sharing systems within contrasting contexts (one located in a developed country and the other in an emerging economy) which is still scarcely discussed in the literature. One of the bike-sharing systems under study is located in Brazil (refer to Mobilicidade, 2014) and the other one in France (refer to Vélib', 2014); the latter is one of the largest in the world and may be considered as a benchmark. This type of business model is promising for both industrialized and emerging contexts (Ceschin, 2014) and, therefore, they were selected in order to compare the main differences according to each economy reality.

To analyze and compare both PSS solutions, it could be useful to view a bike-sharing system through some lenses. Thus, these PSS solutions were analyzed considering the following aspects: (i) PSS conceptual elements (mainly products and services); (ii) sustainable business models elements, according to the sustainable business model framework (Figure 2) proposed by Bocken and Short (2015) and (iii) PSS sustainability potential, concerning some sustainability aspects discussed in the literature (Table 2).

Table 2. Sustainability aspects considered to analyze the bike-sharing systems

\begin{tabular}{|c|c|c|}
\hline $\begin{array}{l}\text { Sustainability } \\
\text { dimension }\end{array}$ & Aspects & References \\
\hline \multirow{12}{*}{ Environmental } & Greenhouse gases & \\
\hline & emission & Manzini and \\
\hline & Efficient use of & Vezzoli (2003) \\
\hline & resources & \\
\hline & Energy & \\
\hline & consumption & Omman (2003) \\
\hline & & Partidario et al. (2007) \\
\hline & Efficient & Lee et al. (2012) \\
\hline & transportation & Hu et al. (2012) \\
\hline & & Omman (2003) \\
\hline & Health and safety & Lee et al. (2012) \\
\hline & & Hu et al. (2012) \\
\hline \multirow[t]{4}{*}{ Social } & & Mont (2004) \\
\hline & Consumer & Devischer and Mont (2008) \\
\hline & acceptance & Hu et al. (2012) \\
\hline & & Armstrong et al. (2015) \\
\hline \multirow{4}{*}{ Economic } & & Omman (2003) \\
\hline & Added value & Devischer and Mont (2008) \\
\hline & & Hu et al. (2012) \\
\hline & Competitiveness & Omman (2003) \\
\hline
\end{tabular}

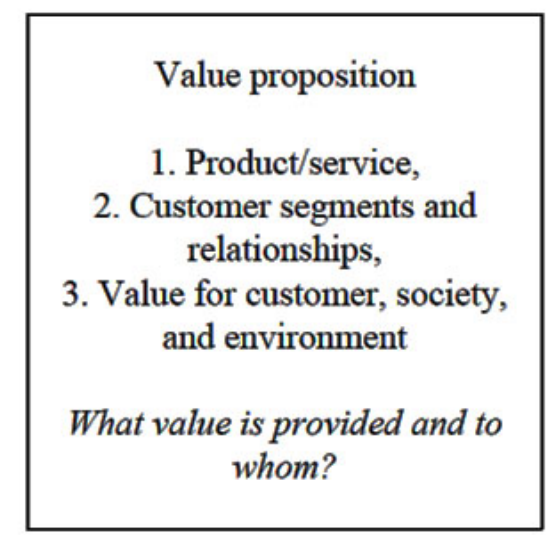

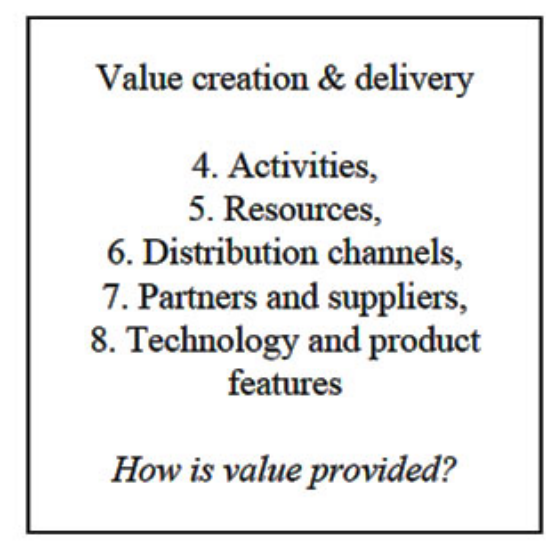

Figure 2. Sustainable business model framework. Source: Bocken et Short (2015)

Value capture
9. Cost structure \& revenute
streams,
10. Value capture for key actors
incl. environment \& society,
11. Growth strategy/ethos
How does the company make
money and capture other forms
of value?


Brazilian Journal of Operations \& Production Management

Volume 13, Número 3, 2016, pp. 264-275 DOI: 10.14488/BJOPM.2016.v13.n3.a4

To collect data, on-site observations were performed, and secondary sources were also used (e.g. other publications about the systems available in the literature, information from service providers' website, and informal visits to the one in Paris). Firstly, an overview of both systems and contextual conditions were carried out and PSS conceptual elements were analyzed. Afterwards, the structure of bike-sharing systems as sustainable business models was described using the framework proposed by Bocken et Short (2015). Finally, an analysis concerning aspects in the three sustainability dimensions was carried out to compare both PSS and some similarities and differences between the systems were discussed. Next section presents the main results of bike-sharing systems analysis and comparison.

\section{RESULTS AND DISCUSSION}

Bike-sharing systems are solutions with potential to offer many benefits to urban contexts both for cycling as transportation mode and for population leisure (Fishman et al., 2013; O'Brien et al., 2014). They have been discussed as a healthy, efficient and cheap option for dense urban environments (O'Brien et al., 2014). The two bike-sharing systems under study are initially analyzed concerning the description of the business context, which provides information about how users interact with the system, how it is controlled, who are the actors involved, their respective roles and interactions ( Keskin, 2006). Each bike-sharing system is presented separately in the following sections.

\subsection{Bike Rio System}

The first PSS is the Bike Rio system located in Rio de Janeiro, Brazil. It has been in operation since 2011. The main goal of the Bike Rio system is to introduce the bicycle as a non-polluting and healthy public transport in order to combat sedentary lifestyles, to reduce traffic congestion, environmental pollution, and to promote social responsibility (Mobilicidade, 2014). The system is an initiative of the city hall and is managed by a private company, selected in a bidding process. This PSS also has a private bank as a partner.

The system comprises 60 stations with a total of 600 bikes, daily operating from $6 a \mathrm{~m}$ to $12 \mathrm{am}$. Customers can use a bicycle (available at the stations) for 60 minutes and after this period to return it to any other station. The user can only rent another bicycle after 15 minutes. To make the registration in the system customers must have a mobile phone to be used as an interface with the system. The payment is made by credit card. There are two registration options: a daily plan or a monthly plan. The rent for periods up to one hour is included in the registration fee. Other fees are applied when the customer overextend one hour using the bike.
Bike Rio bicycles have a differentiated painting for facilitating its identification and they are equipped with electronic tags (Serttel, 2014). Each station has between 24 and 28 bicycles available. The user interface at the stations is powered by solar energy through panels installed in each station. The bicycle was designed to meet the Brazilian traffic code rules, concerning the basic safety items. The bikes are, however, compatible with most commercial models. When this occurs it could facilitate vandalism (Keskin, 2006) and accessories theft.

At the stations there is general information for users concerning system usage, the location of stations around the city, etc. There are also supporting vehicles that are used to transport, perform bicycles maintenance, and to distribute the bicycles among the stations in case of larger imbalance. Preventive and corrective maintenance services are performed by the service provider (Serttel, 2014). The service provider also controls the bicycles distribution among stations in real time (Serttel, 2014). Next section introduces the second PSS under study, located in France.

\subsection{Paris Vélib' System}

The Vélib' bike-sharing system is located in Paris, France, in operation since 2007. Vélib' has 1,800 stations and around 20,600 bicycles. It represents a transportation alternative by complementing the urban public transportation. The Paris Vélib' is operated and managed by a private company, but it is an initiative of the city hall. The city hall is responsible for the maintenance and expansion of infrastructure, necessary for the system operation. The services provided by the private company include the bicycles and stations availability, bicycles maintenance, daily bike redistribution among the stations, and customer service. The system operates 24 hours a day, seven days a week. Customers can withdraw a bicycle at a station, use it for 30 minutes and return it to any of the 1,800 stations across the city. When the customer uses the bike for an extra time, additional fees are charged. However, the customers can return the bike at any station and rent another immediately. The rental plans vary, and they are adaptable to different customer profiles and needs. The purchase of short-term tickets can be made at stations, using credit cards. For the users of Paris metropolitan transport that have a specific card, it is possible to use it in the Vélib' system as well.

The bicycles are developed by the service provider, and they are designed to support intensive use (Bikeoff, 2008). The bikes from the Velib' have a differentiated design. They are manufactured with special components for differentiating it from the commercial bicycles in order to minimize acts of vandalism (Bikeoff, 2008). The bicycles are also designed for safety. At the station, there is a terminal where the customer can buy the tickets or register in the 
system in addition to individual docks for locking the bicycles to protect it. The dockings may vary in quantity between 12 and 70 , according to the demand of the station (Nycdcp, 2009).

One of the strengths of the Paris system is the large amount of stations available. They are spaced at an average distance of 300 meters (Velib, 2014). This proximity facilitates the access to users. Nevertheless, due to the possibility of returning the bicycle to any station, the system finds difficulties regarding the distribution of the bikes. To promote a balance of the bikes distributed among stations, the system has vehicles that are used for the transportation of bikes from saturated stations to others that are empty (Bikeoff, 2008). Another important aspect is the maintenance of the bikes that are performed daily by specialized employees to ensure that users always find a suitable bike at one station when they need. The following section presents the PSS elements identified in the two bikesharing systems and the business model components.

\subsection{Bike-sharing elements and sustainable business models components}

Firstly, it is possible to identify products and services developed as part of an integrated system in both systems. Different actors such as the city hall, the companies (service providers), the population, and the financing agents represent the actors' network. Both systems are dependent on a supporting infrastructure such as stations, public spaces, and bike paths. The main service on both PSS is the provision of bicycles for transportation purposes. Equipment maintenance and customer service also support the system. Three main products were identified in both systems for comparison: bicycles, stations and support vehicles. Table 3 presents the aspects used and results for a comparison between the products of each bike-sharing system.

Concerning the aspect 'similarities with commercial bicycles', the bikes components were analyzed concerning components similarities to commercial bikes. As mentioned earlier, this aspect is important to protect the system against vandalism, by preventing that the equipment can be disassembled by users. This also increases the life cycle of the system and it allows reducing the maintenance costs. The differenced design is an important factor because it allows that bikes could be easily identified by the public, traffic, and security agents. The bicycles in the Bike Rio are mainly differentiated by color and by the presence of advertisement of the bank that sponsors the system. The bicycles of Velib' are identified by the distinctive design; the saddle adjustment aspects are important to allow the use of bicycles by more people with distinct anthropometric characteristics. The brakes, weight, the presence of baskets, and locks that allows stops during the bike use are attractive factors of the system. The presence of brakes, bell, rearview mirror, and bright color (the last two aspects only in the case of Bike Rio) are important aspects for user safety in the traffic.

Table 3. Comparative analysis of products

\begin{tabular}{|c|c|c|c|}
\hline Product & Aspect & Bike Rio & Paris Vélib' \\
\hline \multirow{10}{*}{$\frac{\mathscr{y}}{\frac{\mathscr{\omega}}{\ddot{D}}}$} & Similarity with commercial bicycles & Yes & No \\
\hline & Design differentiated & Yes (color) & Yes (design) \\
\hline & RFID tags & Yes & Yes \\
\hline & Publicity in the bikes & Yes & No \\
\hline & Saddles & Individually regulated & Individually regulated \\
\hline & Frame & Aluminum & Steel \\
\hline & Weight & $16 \mathrm{~kg}$ & $22 \mathrm{~kg}$ \\
\hline & Brake & on handlebar & on handlebar \\
\hline & Bike tire & Common & Anti-theft system \\
\hline & Baskets & Yes & Yes \\
\hline \multirow{7}{*}{ 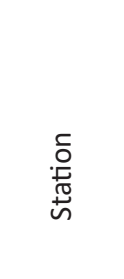 } & Rearview mirror & Yes & No \\
\hline & Bells & Yes & Yes \\
\hline & Locks & Yes & No \\
\hline & Bikes capacity & 12 to 28 & 12 to 70 \\
\hline & Panel for customer interaction & No & Yes \\
\hline & Information to customers & Yes & Yes \\
\hline & Powered by renewable energy & Yes & No \\
\hline \multirow{2}{*}{ 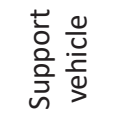 } & Equipped with tools to perform bikes maintenance & Yes & Yes \\
\hline & Space for bicycles transportation & Yes & Yes \\
\hline
\end{tabular}


Table 4. Comparative analysis of services

\begin{tabular}{|c|c|c|c|}
\hline \multicolumn{2}{|l|}{ Aspect } & Bike Rio & Paris Vélib \\
\hline \multicolumn{4}{|c|}{ Back office services } \\
\hline \multirow{3}{*}{\multicolumn{2}{|c|}{$\begin{array}{l}\text { Safety } \\
\text { Maintenance services } \\
\text { Front office services }\end{array}$}} & Yes & Yes \\
\hline & & Yes & Yes \\
\hline & & \multicolumn{2}{|c|}{ Front office services } \\
\hline \multirow{3}{*}{ 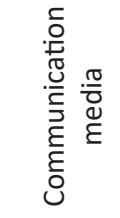 } & Customer service center & Yes & Yes \\
\hline & Internet & Yes & Yes \\
\hline & Stations & Yes & Yes \\
\hline \multirow{5}{*}{ 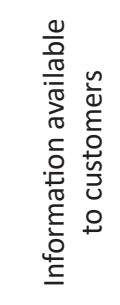 } & Map of the city & Yes & Yes \\
\hline & Map of the stations & Yes & Yes \\
\hline & Bikes availability in each station (real time) & Yes (by phone) & Yes (in the station) \\
\hline & System operation guide & Yes & Yes \\
\hline & Registration and customer query over the internet & Yes & Yes \\
\hline \multirow{6}{*}{ 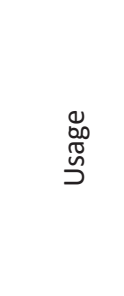 } & Bikes reservation & No & No \\
\hline & Integration with other transportation modes & No & Yes \\
\hline & Customer loyalty programs & No & Yes \\
\hline & Possibility of returning the bike in different stations & Yes & Yes \\
\hline & Operation $24 \mathrm{~h} /$ day & Yes & Yes \\
\hline & Operation during the all days of week & Yes & Yes \\
\hline \multirow{3}{*}{ 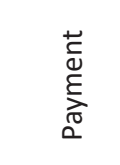 } & Minimum value & $\mathrm{R} \$ 5$ & $€ 1,70$ \\
\hline & Flexibility in payment & Only cards are accepted & Only cards are accepted \\
\hline & Payment options by time & Yes & Yes \\
\hline
\end{tabular}

The stations have different systems, but some important aspects were identified such as: bicycles capacity per station, user interaction, and communication with the system. The supportive vehicles were evaluated by general aspects, since it concerns aspects focused on system maintenance, and there is no interaction with customers. Those are aspects of the services provided by the back office.

The services offered by the two systems were grouped in order to enable a comparative analysis of them. The analysis was divided into back office services and front office services. Table 4 shows some aspects of the services that were selected for comparing both systems. The main service (the bicycle provision) is offered during all day in the Vélib' system while in the Bike Rio it is offered only 18 hours per day. Furthermore, the integration of another urban transportation is only possible in the Vélib' system. In both systems, the customer pays only for the time the product is used, but only credit cards are accepted.

Another important aspect is the customer loyalty strategies in both systems. Paris Vélib' has a customer loyalty program for customers that make an annual subscription, with a number of benefits. In the Bike Rio system, there is the possibility of purchasing a monthly pass, but the customer must create a new account after 30 days. Concerning payment conditions, the credit card is the only method of payment accepted in both cases, because this option is safer for the service provider and it allows reducing the vandalism, since customers authorize the charge in their credit cards in case of problems with the bikes.

Regarding bike-sharing systems as sustainable business models, the value proposition for the customers and society consists of providing a safe and affordable mobility option. The interests of the service provider and customers are aligned because the former aims to contribute to the provision of a transportation option at an affordable cost for the latter (social value), while simultaneously earning profits from the rental service (economic value). For the environment, the system is aimed at providing a transportation alternative that allows pollution emission reduction. The products of the system are planned for a low energy consumption and low waste generation. A balance was observed between the economic, social, and ecological values. 
The value is created from the integration of the bicycles manufacturer, service provider, city hall and other partners (e.g. the bank in the case of Bike Rio). The bikes are designed to be reparable and upgradable to minimize material consumption, waste generation, and new bikes production. The service providers have direct contact with the customers, which allow them to identify the customers' needs and improve service quality. This relationship allows for the effective management of the system and also enhances customer confidence.

The value capture is structured to allow more people, even those with fewer economic possibilities to access to a transportation mode at a cheaper rate. The low cost in comparison with other transportation options is an incentive for customer use. The economic benefits, costs, and responsibility for service provision are shared between the actors. Through the analysis of bike-sharing elements and sustainable business models components, some issues related to the PSS sustainability potential have been identified and are discussed in the next section.

\subsection{Analysis of bike-sharing systems sustainability potential}

Both bike-sharing systems are less polluting options than conventional transportation modes, and can provide many sustainable benefits. The Bike Rio system is part of a lowcarbon development program. This unprecedented program launched at the Rio +20 is a partnership between the city of Rio de Janeiro and the World Bank, and is certified to ISO 9001 quality standard. The program aims to accumulate the carbon credits generated in the main city sustainable programs (World Bank, 2012). In the future, the goal is to sell these credits on the international market. Thus, in addition to environmental benefits, the project will provide economic benefits that will be converted into social investments in the city (World Bank, 2012). So far, the system has accumulated $1,760.60$ tons of carbon credits (Mobilicidade, 2014).

In addition, the Bike Rio system is powered by solar energy to meet the demand required for the system operation, contributing to energy consumption reduction and the reduction of greenhouse gases emissions, since solar energy is a clean and a renewable source. Regarding resources use, the periodic maintenance allows increasing the bicycle useful life, generating less waste and, therefore, reducing resources use, and the manufacture of new bicycles. In the Vélib' system, the vehicles for bicycles distribution among stations are electric (Hemne et al., 2010), which also contributes to minimizing greenhouse gases emissions.

In the social dimension, the bike-sharing systems allow more customers access and represent a transportation alternative for low-income and emerging contexts. In the Vélib' system, there is a fee reduction program that is offered to the beneficiaries of the free public transportation in Paris. It also offers convenience, flexibility, and mobility to the population and it incentives physical activity and health promotion. The reduction of transportation time is another benefit. Both systems have accessible costs and, in the Vélib' system, which has more stations and bicycles, the cost to the user is practically the cost of registration since almost every 300 meters there is a station to pick up and drop off the bike, enabling the user to make a return to 30 minutes. Another benefit that Vélib' system offers is the system's integration with other public transportation modes. The Bike Rio also allows connection to other transportation modes, but is not integrated from the point of view of pass payment and is still restricted to a certain city region. The acceptance of the PSS by customers is positive, and it has been increasing. In Rio de Janeiro, it has been held 4,890,794 trips so far (Mobilicidade, 2014) and this number grows daily. In the Vélib' system, in a survey performed with 853 customers in $2009,94 \%$ of the system' users were 'satisfied' with the service, and more than 50 million loans had been held since PSS launching (Hemne et al., 2010). As both systems have partnerships with the municipal governments, the two PSS are aligned with the city's planning and have the potential to improve the community environment.

In the economic dimension, PSS allows gains to all stakeholders. The customer has benefits because the price is affordable, smaller than the use of other public transport modalities (in Rio Bike the cost to the user is US\$ 3.50 monthly, limited to 60 minutes use between pick up a bicycle and drop off it at a station, but with unlimited use). In the Vélib,' the cost is around US\$ 2.7 per month ( $€ 29$ per year) for unlimited use, but limited to 30 minutes between bicycle pick-up and return it to a station. In the Bike Rio, the sponsor bank, and the company have profits from the bicycles loans as well as with the publicity. In the case of the bank, the bike-sharing system adds value to its business, and it allows improving its competitiveness. Society, in general, wins with a complementary system for urban transportation and with the benefits of carbon credits. In the Vélib' system, the actors earnings are similar. In both systems, there are no other companies offering the same type of service, i.e. there is no competition. Thus, bike-sharing systems provide many environmental, economic and social benefits and represent transportation alternatives with sustainable potential. The following section summarizes the main strengths and weaknesses of each bike-sharing system, identified through the analysis that was performed.

\subsection{Discussion of the main similarities and differences between the bike-sharing systems}

The main difference between the two systems is the design of the products involved. In the Paris Vélib' the bicycles have been developed taking into account intensive 
use. The presence of terminals at the station improves the interface with the customers, making the self-service (service interface) more practical and intuitive. The Bike Rio system uses solar panels for stations power supply, which demonstrates that the system was designed according to the city features and sustainability requirements. The fact that the stations do not have an interface for user interaction was observed as a weakness, since customers need to have a mobile device to access the system. On the other hand, this feature makes the system less vulnerable to vandalism at the stations. The bicycles, however, are not designed for intensive use and for increases in its life cycle.

Another important aspect, concerning the economic dimension, is the revenues from advertising. In the case of Paris Vélib 'system, the service provider has a lot of advertising spots (outdoor). This makes it possible to increase the revenues. A strategic risk in both cases is related to the maintenance of the service provider in the business. The grant is obtained by a bidding process and it can be renewed after the contract expiration. However, there is a risk of the service provider loses the grant after the period. Finally, it was observed that the Paris Vélib' system is more structured than the system of Rio de Janeiro. It should be noted, however, that the Bike Rio system has been in operation since 2011, while Vélib' has been in operation since 2007. The following section presents the main concluding remarks with regard to the PSS solutions analyzed.

\section{CONCLUSIONS AND FUTURE WORK}

Due to the environmental impacts associated with vehicles usage, it is necessary to develop new environmentallyfriendly mobility strategies. The bike-sharing systems under study represent a promising initiative to increase sustainable transport supply in urban contexts. They allow achieving many environmental, economic and social benefits and their implementation on a global level is expanding in recent years.

The implementation of PSS solutions is very dependent of the context it will be located. In the systems analyzed the bikes are designed according the conditions of the city. This aspect reflects the importance of the design phase for a real sustainable solution, because products that are designed without considering the context conditions can become less sustainable solutions than the conventional products. Another important aspect is related to the rebound effects that can be generated when a PSS solution in implemented in a certain context. The contextual conditions should also be taken into account when the rebound effects are analyzed before PSS implementation.

The analysis and comparison between the solutions demonstrated differences in both systems like integration with other transport modes and renewable energy usage that may affect customer acceptance and PSS sustainability performance. Customer behavior, acceptance and satisfaction need further study. Understanding the real factors that motivate customers to use a bike-sharing system in different contexts can be useful in efforts to spread its future use and can help in the understanding of the motivating factors and barriers to PSS acceptance. These factors can be translated into design strategies to facilitate the PSS introduction, and they are important research gaps that must be explored in future work.

\section{ACKNOWLEDGEMENTS}

The authors thank the following Brazilian research agencies: the Coordination for the Improvement of Higher Education Personnel (CAPES) and the National Council for Scientific and Technological Development (CNPq) for the financial support of this research project (grant XXX). This invited article is an extended and enhanced version of the paper presented at the XXX (XXX), held in XXX, XXX in 2015.

\section{REFERENCES}

Armstrong, C. M., et al. (2015), "Sustainable productservice systems for clothing: exploring consumer perceptions of consumption alternatives in Finland", Journal of Cleaner Production, Vol.97, pp.30-39.

Baines, T. S. et al. (2007), "State-of-the-art in productservice systems", Proceedings of the Institution of Mechanical Engineers, Part B: Journal of Engineering Manufacture, Vol.221, No.10, pp.1543-1552.

Beuren, F. H., et al. (2013), "Product-service systems: A literature review on integrated products and services", Journal of Cleaner Production, Vol.47, pp.222-231.

Bikeoff, JCDecaux Schemes: Vélib Paris, Sevici Seville, (FR/ ES) (2008), Available at: http://www.bikeoff.org/design_ resource/dr_PDF/schemes_public_velib_JC_DECAUX_ CYCLOCITY.pdf. (Accessed on 15 December 2014).

Bocken, N. M. P., and Short, S. W. (2015), "Towards a sufficiency-driven business model: Experiences and opportunities", Environmental Innovation and Societal Transitions, In press. doi: http://dx.doi.org/10.1016/j. eist.2015.07.010

Bocken, N. M. P. et al. (2014), "A literature and practice review to develop sustainable business model archetypes", Journal of Cleaner Production, Vol.65, pp. 42-56.

Boehm, M., and Thomas, O. (2013), "Looking beyond the rim of one's teacup: a multidisciplinary literature review of Product-Service Systems in Information Systems, Business Management, and Engineering \&amp; Design", Journal of Cleaner Production, Vol.51, pp.245-260. 
Ceschin, F. (2013), "Critical factors for implementing and diffusing sustainable product-Service systems: Insights from innovation studies and companies' experiences", Journal of Cleaner Production, Vol.45, pp.74-88.

Ceschin, F. (2014), Sustainable Product-Service Systems Between Strategic Design and Transition Studies, Springer, Uxbridge, UK.

Chou, C.J., Chen, C.W., and Conley, C. (2015), "An approach to assessing sustainable product-service systems", Journal of Cleaner Production, Vol.86, pp. 277-284.

Cook, M. (2014), "Fluid transitions to more sustainable product service systems", Environmental Innovation and Societal Transitions, Vol. 12, pp. 1-13.

Devischer, T., and Mont, O. (2008), “An analysis of a product service system in Bolivia: coffee in Yungas. International Journal of Innovation and Sustainable Development", Vol. 3, No. 3-4, pp. 262-284.

Fishman, E., Washington, S., and Haworth, N. (2013). "Bike share: a synthesis of the literature", Transport Reviews, Vol.33, No.2, pp. 148-165.

Fishman, E., Washington, S, and Haworth, N. (2014), "Bike share's impact on car use: Evidence from the United States, Great Britain, and Australia", Transportation Research Part D, Vol.31, pp.13-20.

Fishman, E., Washington, S., Haworth, N. and Watson, A. (2015), "Factors influencing bike share membership: An analysis of Melbourne and Brisbane", Transportation Research Part A, Vol.71, pp.17-30.

Goedkoop, M. et al. (1999), Product Service-Systems, ecological and economic basics, Dutch Ministries of Environment and Economic Affairs. Available at: http:// teclim.ufba.br/jsf/indicadores/holan\%20Product\%20 Service\%20Systems\%20main\%20report.pdf (Accessed on 15 December 2014).

Hemne, S., Orsato, R.J., and Van wassenhove, L. (2010), Vélib': sustainable market space?, Available at: http://www. insead.edu/facultyresearch/faculty/documents/Velib-w. pdf. (Accessed on 15 December 2014).

Hu, H.A. et al. (2012), "Development of sustainability evaluation model for implementing product service systems", International Journal of Environmental Science and Technology, Vol. 9, No.2, pp. 343-354, 2012.

Keskin, D. (2006), Analysis of public use bicycle systems from a Product-Service System perspective, Dissertation (Master of Science in Industrial Design). Middle East Technical University, Ancara.

Lee, S. et al. (2012), "Dynamic and multidimensional measurement of product-service system (PSS) sustainability:
A triple bottom line (TBL)-based system dynamics approach", Journal of Cleaner Production, Vol. 32, pp. 173-182.

Manzini, E., and Vezolli, C. (2003), "A strategic design approach to develop sustainable product service systems: examples taken from the 'environmentally friendly innovation' Italian prize", Journal of Cleaner Production, Vol. 11, No.8, pp. 851857.

Meredith, J. (1998), "Building operations management theory through case and field research", Journal of Operations Management, Vol.16, No.4, pp. 441-454.

Mobilicidade (2014) About Bike Rio System. Available at: http://www.mobilicidade.com.br/siteoficial (Accessed on 15 December 2014).

Mont, O. (2004), Product-service systems: panacea or myth?, Doctoral (Dissertation) - The International Institute for Industrial Environmental Economics (IIIEE), Lund University, Sweden.

Mont, O., and Tukker, A. (2006), "Product-Service Systems: reviewing achievements and refining the research agenda", Journal of Cleaner Production, Vol. 14, No. 17, pp. 1451-1454, 2006.

New York city department of city planning (Nycdcp) (2009), Bike Share: opportunities in New York City. Available at: http://www.nyc.gov/html/dcp/pdf/transportation/bike_ share_complete.pdf (Accessed on 15 December 2014).

O'brien, O., Cheschire, J., and Batty, M. (2014), “Mining bicycle sharing data for generating insights into sustainable transport systems", Journal of Transport Geography, Vol. 34, pp. 262-273.

Omann, I. (2003), "Product service systems and their Impacts on sustainable development: a multi-criteria evaluation for Austrian companies" paper presented at: Proceedings of ASCW Frontiers, Adelaide.

Overholm, H. (2015), "Alliance formation by intermediary ventures in the solar service industry: implications for product-service systems research", Journal of Cleaner Production, In press. doi: http://dx.doi.org/10.1016/j. jclepro.2015.07.061

Partidario, P.J., Lambert, J. and Evans, S. (2007), "Building more sustainable solutions in production-consumption systems: the case of food for people with reduced access", Journal of Cleaner Production, Vol. 15, No.6, pp. 513-524.

Reim, W., Parida, V.,and Örtqvist, D. (2015), "ProductService Systems (PSS) business models and tactics - a systematic literature review", Journal of Cleaner Production, Vol.97, pp. 61-75.

Serttel. Sobre a Serttel. Available at: http://www.serttel. com.br/samba.htm. (Accessed on 15 December 2014). 
Tran, T. D., Ovtracht, N., and d'Arcier, B. F. (2015), "Modeling Bike Sharing System using Built Environment Factors", Procedia CIRP, Vol. 30, pp. 293-298.

Tukker, A. (2004), "Eight types of product-service system: Eight ways to sustainability? Experiences from suspronet", Business Strategy and the Environment, Vol.13, No.4, pp.246-260.

Tukker, A. (2015), "Product services for a resourceefficient and circular economy - A review", Journal of Cleaner Production, Vol.97, pp.76-91.

Tukker, A., and Tischner, U. (2006) "Product-services as a research field: past, present and future. Reflections from a decade of research", Journal of Cleaner Production, Vol. 14, No. 17, pp. 1552-1556, 2006.

United Nations Environment Programme (Unep) (2002), Product-Service Systems and Sustainability: opportunities for sustainable solutions, Milan. Available at: http://www. unep.org/resourceefficiency/Portals/24147/scp/design/ pdf/pss-imp-7.pdf. (Accessed on 18 August 2015)

United Nations Environment Programme (Unep) (2015), Using product-service systems to enhance sustainable public procurement, Available at: http://www.unep.org/10yfp/ Portals/50150/10YFP\%20SPP/3A_Technical\%20report.pdf. (Accessed on 18 August 2015)

Velib (2014), Available at: http://www.velib.paris/ (Accessed on 16 December 2014).

Vezzoli, C. (2007), System design for sustainability: theory, methods and tools for a sustainable "satisfaction-system" design, Rimini, Maggioli.

Vezzoli, C., Ceschin, F., Diehl, J. C., and Kohtala, C. (2015), "New design challenges to widely implement 'Sustainable Product-Service Systems", Journal of Cleaner Production, Vol.97, 1-12.

World Bank (2012), Rio de Janeiro lança programa para reduzir gases do efeito estufa. Available at: http://www. worldbank.org/pt/news/feature/2012/06/18/rio-dejaneiro-to-fight-greenhouse-gas-emissions. (Accessed 19 December 2014).

Zhang, L., Zhang, J., Duan, Z.-y., and Bryde, D. (2015), "Sustainable bike-sharing systems: characteristics and commonalities across cases in urban China", Journal of Cleaner Production, Vol.97, No.124-133. 